\title{
CA19-9 Concentration After First-line Chemotherapy Is Prognostic Predictor of Metastatic Colon Cancer
}

\author{
RYOSUKE HASHIZUME ${ }^{1}$, HIDEJIRO KAWAHARA ${ }^{2}$, MASAICHI OGAWA ${ }^{3}$, \\ KATSUHITO SUWA ${ }^{4}$, KEN ETO $^{1}$ and KATSUHIKO YANAGA ${ }^{1}$ \\ ${ }^{1}$ Department of Surgery, The Jikei University School of Medicine, Tokyo, Japan; \\ ${ }^{2}$ Department of Surgery, Kashiwa Hospital, The Jikei University School of Medicine, Chiba, Japan; \\ ${ }^{3}$ Department of Surgery, Katsushika Medical Center, The Jikei University School of Medicine, Tokyo, Japan; \\ ${ }^{4}$ Department of Surgery, the Third Hospital, The Jikei University School of Medicine, Tokyo, Japan
}

\begin{abstract}
Background/Aim: To evaluate whether the serum levels of CEA or CA19-9 concentration is a useful predictor of survival in patients with metastatic colon cancer (mCC). Patients and Methods: Between 2012 and 2015, 113 patients with $m C C$ who underwent chemotherapy according to the Japanese Colorectal Cancer Treatment Guidelines at four Jikei University Hospitals were enrolled in this study. The two serum tumor makers, CEA and CA19-9 were measured before first-line chemotherapy and at four months thereafter. Results: Serum CA19-9 concentration at four months after first-line chemotherapy $(p=0.003, H R=3.761)$ and first-line chemotherapy including oxaliplatin ( $p=0.038, H R=0.312$ ) were independent predictors of survival in patients with $m C C$. By excluding the transverse colon, only serum CA199 concentration at four months after first-line chemotherapy $(p=0.005, H R=3.660)$ was identified as the predictor of survival. Conclusion: Serum CA19-9 concentration after first-line chemotherapy seems to be a useful predictor of survival in patients with $m C C$.
\end{abstract}

Until the 1980s, colorectal cancer had been regarded as a cancer marginally affected by chemotherapy. In the early 1990s, two new anticancer drugs, irinotecan (CPT-11) and oxaliplatin (1-15) attracted attention, and new regimens with strong anticancer effects, such as infusion of fluorouracil and leucovorin combined with either irinotecan (FOLFIRI) (1-3,

This article is freely accessible online.

Correspondence to: Ryosuke Hashizume, MD, Department of Surgery, Jikei University School of Medicine, 3-25-8 Nishishinbashi, minatoku, Tokyo 105-8461, Japan. Tel: +81 334331111 Ext. 3421, Fax: +8134358677, e-mail: hashihide@jikei.ac.jp

Key Words: CA19-9, CEA, metastatic colorectal cancer, predictor.
$5,8,14,15)$ or oxaliplatin (FOLFOX) $(1,4-8,12,13)$ were introduced for patients with metastatic colorectal cancer (mCRC). During the last decade, the clinical outcomes of patients with $\mathrm{mCRC}$ have improved due to combination of the aforementioned regimens with antiangiogenetic drug or anti-epidermal growth factor receptor agents. The median overall survival (OS) for patients with mCRC is currently estimated to exceed 30 months $(6-8,12-15)$.

RAS, phosphatidylinositol-4,5-bisphosphate 3-kinase catalytic subunit alpha (PIK3CA), and BRAF have gained attention as predictors of the effect of chemotherapy and have been used to determine the indications for combined treatment with anti-epidermal growth factor receptor agents (9-11). Generally, predictors used in colorectal cancer include serum levels of the tumor markers, carcinoembryonic antigen (CEA) and carbohydrate antigen 19-9 (CA19-9); however, whether serum CEA and CA19-9 concentrations are useful predictors of survival in patients with metastatic colon cancer (mCC) remains unclear. The aim of this retrospective study was to evaluate whether serum CEA and CA19-9 concentration are useful predictors of survival of patients with $\mathrm{mCC}$.

\section{Patients and Methods}

The Ethics Committee for Biomedical Research of the Jikei Institutional Review Board approved the protocol of this retrospective study (30-431(9452)). Between 2012 and 2015, 113 patients with $\mathrm{mCC}$ whose primary tumor lesion was resected, and were 80 years of age or younger, underwent chemotherapy according to the Japanese colorectal cancer treatment guidelines at four Jikei university hospitals, who were enrolled into this study. Serum CEA and CA19-9 levels were measured twice: once before first-line chemotherapy and then at four months after starting chemotherapy, the latter being performed to evaluate the resectability of metastatic lesions. The cutoff values for serum CEA and CA19-9 concentrations were $50 \mathrm{ng} / \mathrm{ml}$ and $37 \mathrm{U} / \mathrm{ml}$, respectively. 
This study consisted of 64 male and 49 female patients with a mean age of 66.1 years (range: 38-80 years). Eighty-seven patients (77\%) had metastatic recurrence in only one organ, and the other 26 patients $(23 \%)$ had metastatic recurrence in two or more organs. The liver was the most common organ with metastatic recurrence, occurring in 77 patients $(68 \%)$, followed by lung in 24 patients (24\%) and peritoneal dissemination in 35 patients $(31 \%)$. One hundred and two patients $(90 \%)$ were administered oxaliplatinbased regimen (FOLFOX, S-1 plus oxaliplatin (SOX) $(6,12)$, capecitabine plus oxaliplatin (XELOX) (13)) as the first-line chemotherapy, while 11 patients $(10 \%)$ were given CPT-11-based regimens (FOLFIRI, irinotecan plus S-1 (IRIS) (14), irinotecan plus capecitabine (XELIRI) (15)) as the first-line chemotherapy. Only two patients ( $2 \%$ ) underwent conversion surgery (Table I).

Statistical analysis. Continuous variables were expressed as a mean and range. $\chi^{2}$ test was used for comparison of categorical data, and $t$-tests were used for comparison of continuous variables. The Kaplan-Meier method was used to calculate survival rates, and the Wilcoxon test was used for comparison of survival rates. Cox proportional hazard regression model was used to analyze the predictive factors for the effect of chemotherapy. A $p$-value of less than 0.05 was considered to indicate significance. All data were analyzed with the IBM SPSS Statistics software, version 22.0 (IBM Japan, Ltd, Tokyo, Japan).

\section{Results}

Correlation between the effect of chemotherapy and each factor (Table II). To determine the variables affecting survival after starting chemotherapy, 10 parameters (age, gender, pathological type of the primary tumor, number of metastatic sites, CEA and CA19-9 levels before and at four months after starting chemotherapy, and first-line regimen) were analyzed using Cox proportional hazard regression. Only two factors, serum CA19-9 levels ( $p=0.003$; $\mathrm{HR}=3.761)$ at four months after starting chemotherapy and the use of an oxaliplatin-based regimen as first line chemotherapy $(p=0.04 ; \quad H R=0.312)$ were independent contributing factors to predict survival after chemotherapy.

Comparison of primary cancer sites in the right- and leftside colons (Table III). In subgroup analysis for primary tumor located in right or left side colon, 15 patients with transverse colon cancer were excluded and the other 98 patients, 47 right-sided and 51 left-sided were selected. The number of patients with the serum CA19-9 levels above 37.0 $\mathrm{U} / \mathrm{ml}$ at four months after starting chemotherapy was significantly higher in patients with right-side colon cancer as compared to those with left-side colon cancer $(p=0.05)$. A larger percentage of patients with left-sided colon cancer were treated with bevacizumab as compared to patients with right-sided colon cancer ( $84 \%$ vs. $53 \%, p=0.002)$.

Correlations between the effect of chemotherapy and various factors depending on location of the primary cancer site (Table
Table I. Characteristics of the patients with colon cancer

\begin{tabular}{lc}
\hline Variable & $\mathrm{n}=113$ \\
\hline Age (years) & $66.1(38-80)$ \\
Gender & \\
Male & $64(57)$ \\
Female & $49(43)$ \\
Pathology of primary tumor & \\
Well differentiated adenocarcinoma & $49(43)$ \\
Moderately differentiated adenocarcinoma & $59(55)$ \\
Other & $5(5)$ \\
Number of metastatic sites & $87(77)$ \\
Only one site & $26(23)$ \\
More than two sites & \\
Metastatic site & $77(68)$ \\
Liver & $24(21)$ \\
Lung & $35(31)$ \\
Peritoneum & $4(4)$ \\
Other & $102(90)$ \\
Regimen of the first line & $11(10)$ \\
FOLFOX, SOX, XELOX & $2(2)$ \\
FOLFIRI, IRIS, XELIRI & \\
Conversion surgery & \\
\hline
\end{tabular}

The data are presented as mean (range) or as $\mathrm{n}(\%)$.

$I V)$. In order to determine the variables affecting survival after starting chemotherapy, 12 parameters (age, gender, pathological type of the primary tumor, number of metastatic sites, CEA and CA19-9 levels before and four months after starting chemotherapy, and first line regimen including $\mathrm{Bmab}$ or $\mathrm{Cmab}$ ) were analyzed using the Cox proportional hazard regression in the subgroup. Only one factor, serum CA19-9 levels ( $p=0.005$; $\mathrm{HR}=3.660$ ) at four months after starting chemotherapy were the independent contributing factor to predict survival after starting chemotherapy. However, no significant difference was observed regarding the site of the primary cancer (left or right) $(p=0.65)$.

Comparison of cumulative survival rates depending on the location of the primary cancer (Figure 1). We compared the prognosis based on the site of the primary cancer. We found no significant difference in overall survival between leftsided and right-sided colon cancer $(p=0.50)$ and demonstrated no significant superiority of prognosis in patients whose primary cancer site were left-side colon, over those whose primary cancer site were right-side colon.

Differences in tumor marker changes before and after chemotherapy (Table V). Evaluation of the changes in serum CEA levels before and at four months after starting chemotherapy revealed that 50 patients $(44 \%)$ had serum CEA levels of $50 \mathrm{ng} / \mathrm{ml}$ or more before starting chemotherapy; this number decreased significantly to 31 
Table II. Correlation between the effect of chemotherapy and each factor

\begin{tabular}{|c|c|c|}
\hline Variable & $\begin{array}{l}\text { Hazard Ratio } \\
\text { (95\% confidence interval) }\end{array}$ & $p$-Value \\
\hline \multicolumn{3}{|l|}{ Age (years) } \\
\hline$\leq 70$ & $1.350(0.739-2.466)$ & 0.329 \\
\hline$>70$ & 1 & \\
\hline \multicolumn{3}{|l|}{ Gender } \\
\hline Female & $1.319(0.758-2.296)$ & 0.328 \\
\hline Male & 1 & \\
\hline \multicolumn{3}{|l|}{ Pathological type of primary tumor } \\
\hline Other & $0.983(0.566-1.706)$ & 0.951 \\
\hline Well differentiated adenocarcinoma & 1 & \\
\hline \multicolumn{3}{|l|}{ Number of metastatic sites } \\
\hline More than two & $1.204(0.637-2.277)$ & 0.567 \\
\hline Only one & 1 & \\
\hline \multicolumn{3}{|l|}{ Conversion therapy } \\
\hline Yes & $1.088(0.105-11.313)$ & 0.944 \\
\hline No & 1 & \\
\hline \multicolumn{3}{|l|}{ Serum CEA level before chemotherapy } \\
\hline$>50.0 \mathrm{ng} / \mathrm{ml}$ & $2.131(0.881-5.152)$ & 0.093 \\
\hline$\leq 50.0 \mathrm{ng} / \mathrm{ml}$ & 1 & \\
\hline \multicolumn{3}{|c|}{ Serum CEA level 4 months after starting chemotherapy } \\
\hline$>50.0 \mathrm{ng} / \mathrm{ml}$ & $0.933(0.428-2.034)$ & 0.861 \\
\hline$\leq 50.0 \mathrm{ng} / \mathrm{ml}$ & 1 & \\
\hline \multicolumn{3}{|l|}{ Serum CA19-9 level before chemotherapy } \\
\hline$>37.0 \mathrm{U} / \mathrm{ml}$ & $0.536(0.217-1.324)$ & 0.177 \\
\hline$\leq 37.0 \mathrm{U} / \mathrm{ml}$ & 1 & \\
\hline \multicolumn{3}{|c|}{ Serum CA19-9 level 4 months after starting chemotherapy } \\
\hline$>37.0 \mathrm{U} / \mathrm{ml}$ & $3.761(1.558-9.081)$ & 0.003 \\
\hline$\leq 37.0 \mathrm{U} / \mathrm{ml}$ & 1 & \\
\hline \multicolumn{3}{|l|}{ First line regimen including oxaliplatin } \\
\hline No & $0.312(0.104-0.936)$ & 0.038 \\
\hline Yes & 1 & \\
\hline
\end{tabular}

patients $(27 \%)$ at four months after starting chemotherapy $(p=0.008)$. In contrast, 59 patients $(52 \%)$ and 51 patients (45\%) had serum CA19-9 levels of $37 \mathrm{U} / \mathrm{ml}$ or more before and at four months after starting chemotherapy, with no statistically significant difference $(p=0.29)$.

\section{Discussion}

With the recent advent of CPT-11, oxaliplatin and molecularly targeted agents, chemotherapy for unresectable recurrent colon cancer has made remarkable progress (6-8, 12-15). Genetic variants of RAS, PIK3CA, BRAF, and UGT1A1 are regarded as prognostic factors for therapeutic agents $(9-11,16)$. Circulating tumor cells (CTCs) are also considered as a prognostic factor $(17,18)$ but determining CTC levels is not currently commonly used due to its high cost and complicated protocol. The most general and inexpensive chemotherapy predictors are serum levels of the tumor markers CEA and CA19-9.

Morita et al. (19) and Louhimo et al. (20) have reported that preoperative serum CEA but not CA19-9 level is a prognostic factor in patients with resectable colon cancer. Conversely, Park et al. (21) have measured preoperative and postoperative levels of serum CEA and CA19-9 in patients with resectable colon cancer and reported that high preoperative levels of serum CA19-9 were an independent risk factor for recurrence, while the postoperative elevation of serum CA19-9 was a factor associated with an increased risk of peritoneal recurrence.

Adam et al. (22) have reported that elevated serum CA199 levels after chemotherapy in unresectable recurrent colon cancer correlated with shortened recurrence-free and overall survival. Similarly, Sakamoto et al. (23) have reported that elevated serum CA19-9 levels after chemotherapy shortened recurrence-free and overall survival, while elevated serum CEA level after chemotherapy was a risk factor for recurrence. Mitsuyama et al. (24) have reported that serum CEA levels of $\geq 100 \mathrm{ng} / \mathrm{ml}$ and CA19-9 levels of $\geq 100 \mathrm{U} / \mathrm{ml}$ before chemotherapy in patients with colon cancer and unresectable liver metastasis were prognostic factors for poor prognosis. Thus, given that there is no consensus on this matter, we evaluated serum CEA and CA19-9 before 
Table III. Comparison of primary cancer sites in the right- and left-side colons.

\begin{tabular}{|c|c|c|c|}
\hline Variable & Right side colon $(n=47)$ & Left side colon $(n=51)$ & $p$-Value \\
\hline \multicolumn{4}{|l|}{ Age (years) } \\
\hline$\leq 70$ & $19(40)$ & $20(39)$ & \multirow[t]{2}{*}{0.903} \\
\hline$>70$ & $28(60)$ & $31(61)$ & \\
\hline \multicolumn{4}{|l|}{ Gender } \\
\hline Female & $19(40)$ & $15(29)$ & \multirow[t]{2}{*}{0.252} \\
\hline Male & $28(60)$ & $36(71)$ & \\
\hline \multicolumn{4}{|l|}{ Pathological type of primary tumor } \\
\hline Other & $26(55)$ & $32(63)$ & \multirow[t]{2}{*}{0.455} \\
\hline Well differentiated adenocarcinoma & $21(45)$ & $19(37)$ & \\
\hline \multicolumn{4}{|l|}{ Number of metastatic sites } \\
\hline More than two & $12(26)$ & $12(24)$ & \multirow[t]{2}{*}{0.818} \\
\hline Only one & $35(74)$ & $39(76)$ & \\
\hline \multicolumn{4}{|l|}{ Conversion therapy } \\
\hline Yes & $0(0)$ & $1(2)$ & \multirow[t]{2}{*}{1.000} \\
\hline No & $47(100)$ & $50(98)$ & \\
\hline \multicolumn{4}{|l|}{ Serum CEA level before chemotherapy } \\
\hline$>50.0 \mathrm{ng} / \mathrm{ml}$ & $20(43)$ & $20(39)$ & \multirow[t]{2}{*}{0.737} \\
\hline$\leq 50.0 \mathrm{ng} / \mathrm{ml}$ & $27(57)$ & $31(61)$ & \\
\hline \multicolumn{4}{|c|}{ Serum CEA level 4 months after starting chemotherapy } \\
\hline$>50.0 \mathrm{ng} / \mathrm{ml}$ & $15(32)$ & $15(29)$ & \multirow[t]{2}{*}{0.788} \\
\hline$\leq 50.0 \mathrm{ng} / \mathrm{ml}$ & $32(68)$ & $36(71)$ & \\
\hline \multicolumn{4}{|l|}{ Serum CA19-9 level before chemotherapy } \\
\hline$>37.0 \mathrm{U} / \mathrm{ml}$ & $27(57)$ & $23(45)$ & \multirow[t]{2}{*}{0.222} \\
\hline$\leq 37.0 \mathrm{U} / \mathrm{ml}$ & $20(43)$ & $28(55)$ & \\
\hline \multicolumn{4}{|c|}{ Serum CA19-9 level 4 months after starting chemotherapy } \\
\hline$>37.0 \mathrm{U} / \mathrm{ml}$ & $26(55)$ & $18(35)$ & \multirow[t]{2}{*}{0.046} \\
\hline$\leq 37.0 \mathrm{U} / \mathrm{ml}$ & $21(45)$ & $33(65)$ & \\
\hline \multicolumn{4}{|l|}{ Additional drug } \\
\hline None & $14(30)$ & $3(6)$ & \multirow[t]{3}{*}{0.002} \\
\hline Bevacizumab & $25(53)$ & $43(84)$ & \\
\hline Cetuximab & $8(17)$ & $5(10)$ & \\
\hline
\end{tabular}

The data are presented as $\mathrm{n}(\%)$.

implementing first-line chemotherapy for unresectable colon cancer and again at four months after starting chemotherapy to determine whether serum CEA and CA19-9 were prognostic factors.

We reported a correlation between serum CEA and CTC levels in which CTC appear when the serum CEA levels were at least 10-fold higher than the normal levels (50 $\mathrm{ng} / \mathrm{ml}$ ), and any subsequent increase in serum CEA was associated with an increase in CTC. Accordingly, the serum CEA cutoff levels in the current study were $50 \mathrm{ng} / \mathrm{ml}(17$, 18). The CA19-9 cut-off levels were set at $37 \mathrm{U} / \mathrm{ml}$ which was the upper normal value.

Analysis of the Cox proportional hazard model revealed significant differences in two factors: the serum CA19-9 levels at four months after starting chemotherapy and the use of an oxaliplatin-based regimen (FOLFOX, SOX, and $\mathrm{XELOX)}$ as the first-line chemotherapy regimen. The prechemotherapy serum CEA and CA19-9 levels were not prognostic factors, which was an unexpected finding. The use of potent oxaliplatin-based chemotherapies, such as
FOLFOX, SOX, and XELOX, as first-line chemotherapy could explain why these levels were not prognostic. Also, the life-prolonging effect of second and third-line therapies might have influenced the outcome.

Analysis of the Cox proportional hazard model regarding differences in primary cancer site (right-side or left-side colon), which has recently become a topic of discussion (2527), revealed a significant difference only in serum CA19-9 levels at four months after starting chemotherapy, and the serum CA19-9 levels had a higher hazard ratio than the difference between the primary cancer being in the left or the right colon. It has been reported that little effect can be expected from anti-epidermal growth factor receptor (EGFR) antibodies as a concomitant drug with chemotherapy in patients with primary cancer in the right-side colon (25-27). In the current study, there were more cases in which angiogenesis inhibitors were used as a concomitant drug with chemotherapy in patients with primary cancer in the rightside colon as compared to anti-EGFR antibodies. In fact, we found no significant difference in overall survival between 
Table IV. Correlations between chemotherapy effect in patients with the primary cancer site in the left or right side of the colon and various factors.

\begin{tabular}{|c|c|c|}
\hline Variable & $\begin{array}{l}\text { Hazard Ratio } \\
\text { (95\% confidence interval) }\end{array}$ & $p$-Value \\
\hline \multicolumn{3}{|l|}{ Age (years) } \\
\hline$\leq 70$ & $0.899(0.487-1.662)$ & 0.736 \\
\hline$>70$ & 1 & \\
\hline \multicolumn{3}{|l|}{ Gender } \\
\hline Female & $1.162(0.627-2.153)$ & 0.632 \\
\hline Male & 1 & \\
\hline \multicolumn{3}{|l|}{ Primary tumor location } \\
\hline Left side colon & $1.157(0.613-2.185)$ & 0.653 \\
\hline Right side colon & 1 & \\
\hline \multicolumn{3}{|l|}{ Pathological type of primary tumor } \\
\hline Other & $0.775(0.399-10503)$ & 0.451 \\
\hline Well differentiated adenocarcinoma & 1 & \\
\hline \multicolumn{3}{|l|}{ Number of metastatic sites } \\
\hline More than two & $0.887(0.456-1.727)$ & 0.724 \\
\hline Only one & 1 & \\
\hline \multicolumn{3}{|l|}{ Conversion therapy } \\
\hline Yes & $0.214(0.019-2.378)$ & 0.724 \\
\hline No & 1 & \\
\hline \multicolumn{3}{|l|}{ Serum CEA level before chemotherapy } \\
\hline$>50.0 \mathrm{ng} / \mathrm{ml}$ & $2.336(0.879-6.207)$ & 0.089 \\
\hline$\leq 50.0 \mathrm{ng} / \mathrm{ml}$ & 1 & \\
\hline \multicolumn{3}{|c|}{ Serum CEA level 4 months after starting chemotherapy } \\
\hline$>50.0 \mathrm{ng} / \mathrm{ml}$ & $0.603(0.229-1.586)$ & 0.305 \\
\hline$\leq 50.0 \mathrm{ng} / \mathrm{ml}$ & 1 & \\
\hline \multicolumn{3}{|l|}{ Serum CA19-9 level before chemotherapy } \\
\hline$>37.0 \mathrm{U} / \mathrm{ml}$ & $0.540(0.212-1.374)$ & 0.196 \\
\hline$\leq 37.0 \mathrm{U} / \mathrm{ml}$ & 1 & \\
\hline \multicolumn{3}{|c|}{ Serum CA19-9 level 4 months after starting chemotherapy } \\
\hline$>37.0 \mathrm{U} / \mathrm{ml}$ & $3.660(1.475-9.085)$ & 0.005 \\
\hline$\leq 37.0 \mathrm{U} / \mathrm{ml}$ & 1 & \\
\hline \multicolumn{3}{|l|}{ First line regimen including Bmab } \\
\hline No & $0.478(0.209-1.092)$ & 0.080 \\
\hline Yes & 1 & \\
\hline \multicolumn{3}{|l|}{ First line regimen including $\mathrm{Cmab}$} \\
\hline No & $0.563(0.186-1.702)$ & 0.309 \\
\hline Yes & 1 & \\
\hline
\end{tabular}

left-side and right-side primary cancers. Using angiogenesis inhibitors as a concomitant drug with chemotherapy may be effective for patients with primary cancer in the right side of the colon.

Assessment of the difference in changes in tumor marker levels before and after chemotherapy revealed a significant reduction of serum CEA levels after chemotherapy and no significant difference in CA19-9 levels. Perhaps, CTC disappeared due to the potent chemotherapy, resulting in the serum CEA levels below the cut-off levels, which disqualified serum CEA as an effective predictor. Patients with a serum CA19-9 levels of $\geq 37 \mathrm{U} / \mathrm{ml}$ at four months after starting chemotherapy had a poor prognosis. Therefore, early switching to a second-line therapy and the selection of a concomitant agent may be worthwhile in this category of patients.
Table V. Differences in tumor marker changes before and after chemotherapy.

\begin{tabular}{llll}
\hline Variable & Normal & Abnormal & $p$-Value \\
\hline $\begin{array}{l}\text { Serum CEA levels } \\
\text { Before chemotherapy }\end{array}$ & $63(56)$ & $50(44)$ & 0.008 \\
$\quad 4$ months after starting chemotherapy & $82(73)$ & $31(27)$ & \\
Serum CA19-9 levels & & & \\
$\quad$ Before chemotherapy & $54(48)$ & $59(52)$ & 0.287 \\
4 months after starting chemotherapy & $62(55)$ & $51(45)$ & \\
\hline
\end{tabular}

The data are presented as $n(\%)$.

In conclusion, serum CA19-9 concentration at four months after first-line chemotherapy seems to be a useful predictor of survival in patients with mCC. 


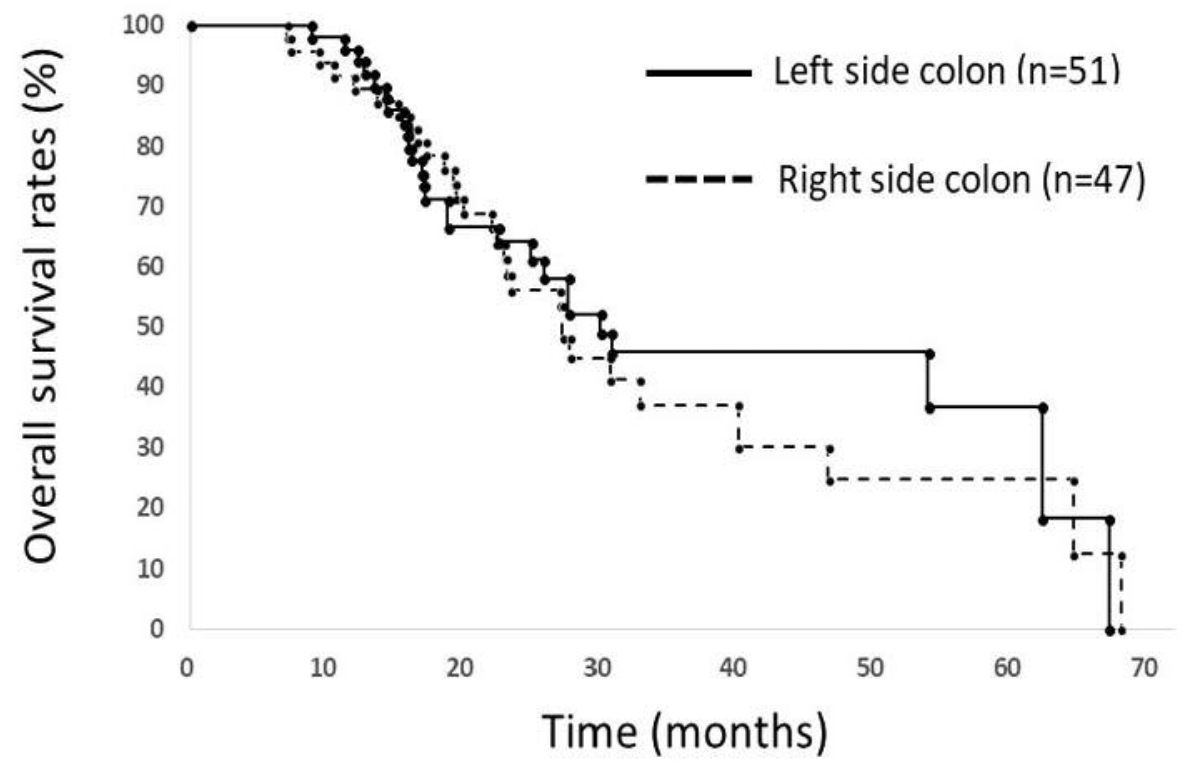

Figure 1. Comparison of overall survival rate after starting chemotherapy between the two groups. No significant difference was demonstrated.

\section{Conflicts of Interest}

The Authors have no conflicts of interest to declare regarding this study.

\section{Authors' Contributions}

All Authors performed operations, analyzed the data of patients regarding their clinical features, and have been involved in drafting the manuscript. KY had given final approval of the version to be published. All Authors read and approved the final manuscript.

\section{References}

1 Tournigand C, André T, Achille E, Lledo G, Flesh M, MeryMignard D, Quinaux E, Couteau C, Buyse M, Ganem G, Landi B, Colin P, Louvet $\mathrm{C}$ and de Gramont A: FOLFIRI followed by FOLFOX6 or the reverse sequence in advanced colorectal cancer: A Randomized GERCOR Study. J Clin Oncol 22: 229237, 2014. PMID: 14657227. DOI: 10.1200/JCO.2004.05.113

2 Delbaldo C, Ychou M, Zawadi A, Douillard JY, André T, GuerinMeyer V, Rougier P, Dupuis O, Faroux R, Jouhaud A, Quinaux E, Buyse $\mathrm{M}$ and Piedbois P; AERO, GERCOR, FNLCC and FFCD: Postoperative irinotecan in resected stage II-III rectal cancer: final analysis of the French R98 Intergroup trial. Ann Oncol 26: 12081215, 2015. PMID: 25739671. DOI: 10.1093/annonc/mdv135

3 Douillard JY, Cunningham D, Roth AD, Navarro M, James RD, Karasek P, Jandik P, Iveson T, Carmichael J, Alakl M, Gruia G, Awad L and Rougier P: Irinotecan combined with fluorouracil compared with fluorouracil alone as first-line treatment for metastatic colorectal cancer: a multicenter randomized trial. Lancet 355: 1041-1047, 2000. PMID: 10744089. DOI: $10.1016 / \mathrm{s} 0140-6736(00) 02034-1$
4 André T, de Gramont A, Vernerey D, Chibaudel B, Bonnetain F, Tijeras-Raballand A, Scriva A, Hickish T, Tabernero J, Van Laethem JL, Banzi M, Maartense E, Shmueli E, Carlsson GU, Scheithauer W, Papamichael D, Möehler M, Landolfi S, Demetter P, Colote S, Tournigand C, Louvet C, Duval A, Fléjou JF and de Gramont A: Adjuvant fluorouracil, leucovorin, and oxaliplatin in stage II to III colon cancer: updated 10-year survival and outcomes according to BRAF mutation and mismatch repair status of the MOSAIC Study. J Clin Oncol 33: 4176-4187, 2015. PMID: 26527776. DOI: 10.1200/JCO.2015.63.4238

5 Kim JH, Choi PR, Park SJ, Park MI, Moon W, Kim SE and Lee GW: Prognostic factors for metastatic colorectal cancer after first-line chemotherapy with FOLFOX-4 or FOLFIRI regimen. Korean J Gastroenterol 63: 209-215, 2014. PMID: 24755745.

6 Yamada Y, Takahari D, Matsumoto H, Baba H, Nakamura M, Yoshida K, Yoshida M, Iwamoto S, Shimada K, Komatsu Y, Sasaki Y, Satoh T, Takahashi K, Mishima H, Muro K, Watanabe M, Sakata Y, Morita S, Shimada Y and Sugihara K: Leucovorin, fluorouracil, and oxaliplatin plus bevacizumab versus $\mathrm{S}-1$ and oxaliplatin plus bevacizumab in patients with metastatic colorectal cancer (SOFT): an open-label, non-inferiority, randomized phase 3 trial. Lancet Oncol 14: 1278-1286, 2013. PMID: 24225157. DOI: 10.1016/S1470-2045(13)70490-X

7 Loupakis F, Cremolini C, Masi G, Lonardi S, Zagonel V, Salvatore L, Cortesi E, Tomasello G, Ronzoni M, Spadi R, Zaniboni A, Tonini G, Buonadonna A, Amoroso D, Chiara S, Carlomagno C, Boni C, Allegrini G, Boni L and Falcone A: Initial therapy with FOLFOXIRI and bevacizumab for metastatic colorectal cancer. N Engl J Med 371: 1609-1618, 2014. PMID: 25337750. DOI: 10.1056/NEJMoa1403108

8 Yamazaki K, Nagase M, Tamagawa H, Ueda S, Tamura T, Murata K, Eguchi N, Nakajima T, Baba E, Tsuda M, Moriwaki T, Esaki T, Tsuji Y, Muro K, Taira K, Denda T, Funai S, Shinozaki K, Yamashita H, Sugimoto N, Okuno T, Nishina T, Umeki M, 
Kurimoto T, Takayama T, Tsuji A, Yoshida M, Hosokawa A, Shibata Y, Suyama K, Okabe M, Suzuki K, Seki N, Kawakami K, Sato M, Fujikawa K, Hirashima T, Shimura T, Taku K, Otsuji T, Tamura F, Shinozaki E, Nakashima K, Hara H, Tsushima T, Ando M, Morita S, Boku N and Hyodo I: Randomized phase III study of bevacizumab plus FOLFIRI and bevacizumab plus mFOLFOX6 as first-line treatment for patients with metastatic colorectal cancer (WJOG4407G). Ann Oncol 27: 1539-1546, 2016. PMID: 27177863. DOI: 10.1093/annonc/mdw206

9 Taniguchi H, Yamazaki K, Yoshino T, Muro K, Yatabe Y, Watanabe T, Ebi H, Ochiai A, Baba E and Tsuchihara K: Japanese Society of Medical Oncology Clinical Guidelines: RAS (KRAS/NRAS) mutation testing in colorectal cancer patients. Cancer Sci 106: 324327, 2015. PMID: 25800101. DOI: 10.1111/cas.12595.

10 Venderbosch S, Nagtegaal ID, Maughan TS, Smith CG, Cheadle JP, Fisher D, Kaplan R, Quirke P, Seymour MT, Richman SD, Meijer GA, Ylstra B, Heideman DA, de Haan AF, Punt CJ and Koopman M: Mismatch repair status and BRAF mutation status in metastatic colorectal cancer patients: a pooled analysis of the CAIRO, CAIRO2, COIN, and FOCUS studies. Clin Cancer Res 20: 5322-5330, 2014. PMID: 25139339. DOI: 10.1158/10780432.CCR-14-0332

11 Therkildsen C, Bergmann TK, Henrichsen-Schnack T, Ladelund $\mathrm{S}$ and Nilbert M: The predictive value of KRAS, NRAS, BRAF, PIK3CA and PTEN for anti-EGFR treatment in metastatic colorectal cancer: a systematic review and meta-analysis. Acta Oncol 53: 852-864, 2014. PMID: 24666267. DOI: 10.3109/ 0284186X.2014.895036.

12 Baba H, Yamada Y, Takahari D, Matsumoto H, Yoshida K, Nakamura M, Yoshida M, Iwamoto S, Shimada K, Komatsu Y, Sasaki Y, Satoh T, Takahashi K, Mishima H, Muro K, Watanabe M, Sakata Y, Morita S, Shimada Y and Sugihara K: S-1 and oxaliplatin (SOX) plus bevacizumab versus mFOLFOX6 plus bevacizumab as first-line treatment for patients with metastatic colorectal cancer: updated overall survival analyses of the open-label, non-inferiority, randomised phase III: SOFT study. ESMO Open 2(1): e000135, 2017. PMID: 28761727. DOI: 10.1136/esmoonpen-2016-000135

13 Cassidy J, Clarke S, Díaz-Rubio E, Scheithauer W, Figer A, Wong R, Koski S, Lichinitser M, Yang TS, Rivera F, Couture F, Sirzén F and Saltz L: Randomized phase III study of capecitabine plus oxaliplatin compared with fluorouracil/folnic acid plus oxaliplatin as first-line therapy for metastatic colorectal cancer. J Clin Oncol 26: 2006-2012, 2008. PMID: 18421053. DOI: $10.1200 /$ JCO.2007.14.9898

14 Muro K, Boku N, Shimada Y, Tsuji A, Sameshima S, Baba H, Satoh T, Denda T, Ina K, Nishina T, Yamaguchi K, Takiuchi H, Esaki T, Tokunaga S, Kuwano H, Komatsu Y, Watanabe M, Hyodo I, Morita $\mathrm{S}$ and Sugihara K: Irinotecan plus S-1(IRIS) versus fluorouracil and folnic acid plus irinotecan (FOLFIRI) as second-line chemotherapy for metastatic colorectal cancer: a randomized phase 2/3 noninferiority study (FIRIS study). Lancet Oncol 11: 853-860, 2010. PMID: 20708966. DOI: 10.1016/S1470-2045(10)70181-9

15 Cui C, Shu C, Yang Y, Liu J, Shi S, Shao Z, Wang N, Yang T and Hu S: XELIRI compared with FOLFIRI as a second-line treatment in patients with metastatic colorectal cancer. Oncol Lett 8: 18641872, 2014. PMID: 25202427. DOI: 10.3892/ol.2014.2335

16 Wang Y, Shen L, Xu N, Wang JW, Jiao SC, Liu ZY and Xu JM: UGT1A1 predicts outcome in colorectal cancer treated with irinotecan and fluorouracil. World J Gastroenterol 18: 66356644, 2012. PMID: 23236239. DOI: 10.3748/wjg.v18.i45.6635
17 Kawahara H, Watanabe K, Toyama Y, Yanagisawa S, Kobayashi $\mathrm{S}$ and Yanaga K: Determination of circulating tumor cells for prediction of recurrent colorectal cancer progression. Hepatogastroenterol 59: 2115-2118, 2012. PMID: 22328299. DOI: $10.5754 /$ hge 11970

18 Neki K, Kawahara H, Watanabe K, Toyama Y, Akiba T and Yanaga $\mathrm{K}$ : Usefulness of circulating tumor cells after preliminary chemotherapy for prediction of response to further anticancer therapy in patients with initially unresectable metastatic colorectal cancer. Anticancer Res 33: 1769-1772, 2013. PMID: 23564832.

19 Morita S, Nomura T, Fukushima Y, Morimoto T, Hiraoka N and Shibata N: Does serum CA19-9 play a practical role in the management of patients with colorectal cancer? Dis Colon Rectum 47: 227-232, 2004. PMID: 15043294. DOI: 10.1007/s10350-0030041-6

20 Louhimo J, Carpelan-Holmstrom M, Alfthan H, Stenman UH, Jarvinen HJ, Haglund C. Serum HCG beta, CA72-4 and CEA are independent prognostic factors in colorectal cancer. Int J Cancer 101: 545-548, 2002. PMID: 12237895.

21 Park IJ, Choi GS and Jun SH: Prognostic value of serum tumor antigen CA19-9 after curative resection of colorectal cancer. Anticancer Res 29: 4303-4308, 2009. PMID: 19846991.

22 Adam R, Delvart V, Pascal G, Valeanu A, Castaing D, Azoulay D, Giacchetti S, Paule B, Kunstlinger F, Ghemard O, Levi F and Bismuth H: Rescue surgery for unrectable colorectal liver metastasese downstaged by chemotherapy: a model to predict longterm survival. Ann Surg 240: 644-657, 2004. PMID: 15383792.

23 Sakamoto Y, Miyamoto Y, Beppu T, Nitta H, Imai K, Hayashi H, Baba Y, Yoshida N, Chikamoto A and Baba H: Postchemotherapeutic CEA and CA19-9 are prognostic factors in patients with colorectal liver metastases treated with hepatic resection after oxaliplatin-based chemotherapy. Anticancer Res 35: 2359-2368, 2015. PMID: 25862901.

24 Mitsuyama Y, Shiba H, Haruki K, Fujiwara Y, Furukawa K, Iida T, Hayashi T, Ogawa M, Ishida Y, Misawa T, Kashiwagi H and Yanaga K: Carcinoembryonic antigen and Carbohydrate antigen 19-9 are prognostic predictors of colorectal cancer with unresectable liver metastasis. Oncol Lett 3: 767-771, 2012. PMID: 22740990. DOI: 10.3892/ol.2012.574

25 Ahmed S, Pahwa P, Le D, Chalchal H, Chandra-Kanthan S, Iqbal $\mathrm{N}$ and Fields A: Primary tumor location and survival in the general population with metastatic colorectal cancer. Clin Colorectal Cancer. PMID: 29221688. DOI: 10.1016/j.clcc.2017.11.001

26 Lu HJ, Lin JK, Chen WS, Jiang JK, Yang SH, Lan YT, Lin CC, Chang SC and Teng HW: Primary tumor location is an important predictive factor for wild-type KRAS metastatic colon cancer treated with cetuximab as front-line bio-therapy. Asia Pac J Clin Oncol 12: 207-215, 2016. PMID: 26935130. DOI: 10.1111/ajco.12469

27 Arnold D, Lueza B, Douillard JY, Peeters M, Lenz HJ, Venook A, Heinemann V, Van Cutsem E, Pignon JP, Tabernero J, Cervantes A and Ciardiello F: Prognostic and predictive value of primary tumour side in patients with RAS wild-type metastatic colorectal cancer treated with chemotherapy and EGFR directed antibodies in six randomized trials. Ann Oncol 28: 1713-1729, 2017. PMID: 28407110. DOI: $10.1093 /$ annonc/mdx 175

Received July 31, 2019

Revised August 14, 2019 Accepted August 22, 2019 